\title{
The Effect of Negotiation of Meaning on the Accuracy in EFL Writing
}

\author{
Manijeh Youhanaee \\ University of Isfahan, Iran \\ Email: youhanaee_m@hotmail.com \\ Afsaneh Rahimi Tehrani \\ University of Isfahan, Iran \\ Faramarz Piri \\ University of Isfahan, Iran
}

\begin{abstract}
This paper reports the results of a study on collaborative writing in a foreign language context, Iran, comparing the performance of one group of Iranian intermediate learners on three different writing tasks: individual writing $(\mathrm{N}=26)$, pair writing $(\mathrm{N}=13)$, and individual writing using a bilingual dictionary $(\mathrm{N}=26)$. When writing in pairs, each pair produced a single text. The participants completed narrative writings based on three different picture-cued stories, one working individually, one in pairs, and another individually using a bilingual dictionary. The performance of the participants in three task conditions was compared on the measure of accuracy, focusing on spelling, morphology and structure. The comparison revealed positive effect of pair work on morphological and structural accuracy but there was no effect on spelling. The analysis of pair-talk recordings during the writing activity provides insights into how the pairs worked on different parts of the language. This study has implications for both foreign language teachers, as well as language testers.
\end{abstract}

Index Terms - accuracy, individual writing, morphology, pair writing, spelling, syntax

\section{INTRODUCTION}

Educational research has considerably indicated that collaboration helps students learn better (e.g., Bossert, 19881989; Johnson \& Johnson, 1992; Kumpulainen \& Mutanen, 2000; Slavin, 1990, 1992; Webb \& Palincsar, 1996). For example, peer teaching has been shown to provide enhanced learning to both the teacher/tutor and to the student (Bargh \& Schul, 1980; Fuchs et al., 1997; Palincsar, Brown, \& Campione, 1993), and cooperative classroom groups have been found to result in greater learning than competitive or individualistically-structured learning environments (Johnson \& Johnson, 1974, 1979, 1989). Collaboration in structured, in-class formats has been shown to increase students' knowledge in a wide range of subjects, including biology (Lazarowitz\&Karsenty, 1990), mathematics (Fuchs et al., 1997; Webb, 1991), composing narratives (Daiute \& Dalton, 1993), and computer programming (Webb, Ender, \& Lewis, 1986). These accumulated research findings have had a significant influence on educational practice. Teachers believe that collaborating groups provide a uniquely effective learning environment (Antil, Jenkins, Wayne, \& Vadasy, 1998). Similarly, both large-scale assessment programs and small-scale in-class assessments increasingly use collaborative group work (Webb, 1995; Webb, Nemer, Chizhik, \& Sugrue, 1998).

Researchers who study collaborative learning have focused on three aspects of interaction that could contribute to learning. First, providing and receiving explanations are both thought to contribute to children's learning (Bargh \& Schul, 1980; Fuchs et al., 1997; Swing \& Peterson, 1982; Vedder, 1985; Webb, 1984, 1991, 1992). Interaction activities between peers in L2 classrooms have been used for building their L2 knowledge, and exposure to more language through the contribution of partners seem to facilitate negotiating ideas and constructing meaning through interpsychological effort to achieve intersubjectivity. For example, Swain and Lapkin (1998) pointed out that learners are able to support L2 learning through questioning, proposing possible solutions, repeating, and negotiating through peer-peer interaction. Second, researchers working within a Piagetian sociocognitive framework have emphasized the mediating role played by conflict and controversy (Bearison, Magzamen,\&Filardo, 1986; Doise \& Mugny, 1984; Miller, 1987; Perret-Clermont, 1980; Piaget, 1948, 1950). Third, researchers working within a Vygotskian or sociocultural framework have emphasized how participants build on each other's ideas to jointly construct a new understanding that none of the participants had prior to the encounter (Forman, 1992; Forman \& Cazden, 1985; Palincsar, 1998).

Thus, the use of group and pair work is widespread in education. The nature of group interaction has been the topic of extensive research in social psychology and general education. In education, for example, there is a large volume of research on cooperative groups (see reviews by Johnson \& Johnson, 1990, 1994; Sharan, 1990; Slavin, 1990).

As Roberts (2006) argues, group assessment can have multiple meanings which include the assessment of the group as a whole, the assessment of individuals within the group, and the assessment of individuals by others in the group. 
Strauss (2001) argues that in many ways group assessment reflects the reality of the real world where group work is increasingly valued in the workplace and where collaborative writing is a common practice. For example, Ede and Lunsford (1990), who surveyed 700 professionals working in seven different fields of endeavor, found that $87 \%$ of the professionals who responded to the survey reported that they worked in a group as a member of a team.

The use of group and pair work is also a common practice in first language (L1) and second language (L2) classes. A number of studies have shown that there are both pedagogic and social gains for most learners working in small groups. For example, in the field of L1 education, studies have shown that learners working in groups are exposed to a greater variety of viewpoints, co-construct new ways of understanding and develop greater critical thinking skills (e.g. Adams \& Hamm, 1996; Barnes \&Todd, 1977; Bygate, 1988; Slavin, 1990; Webb, 1989). Group activities and assessment can assist students in seeking and co-constructing new knowledge through a process of interactions with each other; knowledge that leads to new viewpoints (Vygotsky, 1978).

Leki (2001) points out that while group work tends to be encouraged, it is not always a positive experience for students, particularly when they are working in their second language. However, as Strauss and U (2007) argue, encouraging learners to work in pairs or groups has several benefits. For example if students have difficulty expressing themselves fluently and articulately in English, working with another learner can provide them with the practice they need to improve in this area. They also point out that the ability to work in a group situation, as is often required in the university or the workplace context, involves experience, and so providing that experience for second language learners in the language classroom context is beneficial. As Mutch (1998) points out, group work is used in university settings, not only because it is a good way of developing employability skills, but it is also a means of reducing pressure on resources in higher education.

As Leung (2005) argues, classroom-based assessment can provide pedagogically sound alternatives to standardized testing. He points out that:

The strength and the value of pedagogically oriented classroom teacher assessment lie in its integration with the normal processes of teaching and learning. It can provide useful close-up information on student learning in context. The information generated can also be used indirectly to inform development or change in pedagogy and curriculum, and to provide feedback to students. (2005, p. 48)

Research conducted in L1 settings (e.g., Higgins, Flower, \& Petraglia, 1992; Keys, 1994) has shown that collaborative writing is a way to foster reflective thinking, especially if the learners are engaged in the act of explaining and defending their ideas to their peers. Research conducted with L2 learners (e.g., Donato, 1988; DiCamilla \& Anton, 1997; Storch, 2002; Swain \& Lapkin, 1998) has shown that in the process of co-authoring, learners consider not only grammatical accuracy and lexis but also discourse. Furthermore, and depending on the kind of group/pair dynamics formed (see Donato, 1988; Storch, 2002, 2003), collaborative writing may encourage a pooling of knowledge about language, a process Donato termed collective scaffolding (Donato, 1988, 1994).

Of particular interest is Donato's study (1998), which investigates group work among tertiary students on a writing task. Donato distinguished among different types of groups according to their orientation to the task and the level of interaction. Donato found that learners pooled their knowledge and co-constructed resolutions to a range of language items in groups functioning as a collective. Such pooling of resources or "collective scaffolding" was rare in loosely knit groups. Furthermore, and more importantly, a large proportion of items (75\%) that learners resolved by this process of collective scaffolding subsequently appeared in the learners' individual language production.

In a research conducted by Wigglesworth, G., \& Storch, N. (2009) which was the first study in collaborative writing in a second language context, the participants mostly with Chinese background were asked to write an argumentative essay debating the advantages and disadvantages of exam-based assessment under limited time. They completed the task in two groups, one in pair and another individually. The dialogues of the pairs were recorded and analyzed. The writings were compared on the measures of fluency, accuracy and complexity. This comparison revealed that collaboration impacted positively on accuracy, but did not affect fluency and complexity. They found out working collaboratively in an assessment context will advantage rather than disadvantage learners, in addition to providing them with learning opportunities which in the case of formative classroom assessment is likely to benefit the learners, as well as providing the teacher with insights into how the learners are improving. Thus, while collaborative assessment activities of this type might not be appropriate in high-stakes testing situations, in the classroom context they may address the triple purposes of assessment, learning, as well as providing learners with the kind of experience they require in order to participate productively in group assessment tasks they are likely to encounter in the university context and beyond. The analyses of the pair dialogues suggested that, in terms of the process of writing, when composing in pairs, collaboration afforded the learners the opportunity to interact on different aspects of writing. In particular, it encouraged learners to collaborate when generating ideas about the content of their essays. Pair work activities provided the learners with considerable opportunities to share ideas and pool their language knowledge.

\section{The PRESENT Study}

Since there have been very few studies in collaborative writing in second language context and no study so far in the foreign language context, this study is a further step to investigate empirically how participants working together perform in a writing task in comparison to those working individually in a foreign language context. A point to consider 
is that the study employs a narrative writing task which has never been investigated in collaborative writing. Also, we added a new condition in which the participants were given the opportunity to use a bilingual dictionary (Persian to English) while composing their writings in order to find whether using a bilingual dictionary has any positive effect on their writings in comparison to the individual/pair writings.

Finally, a sample of participants' interactions about language features they were talking about will be examined. Therefore, the first aim was to determine whether participants working in pairs produced better texts than participants writing individually in terms of accuracy. A further aim was to explore the kinds of processes in which the participants engaged during the writing activities so that we could identify what aspects of collaborative writing assessment, if any, can provide learners with opportunities for learning.

\section{A. Research Questions}

1. Do EFL learners perform better in pair writings than in individual writings in terms of spelling, morphology and syntax?

2. Do EFL learners perform better in pair writings than in individual writings using a bilingual dictionary in terms of spelling, morphology and syntax?

3. Do EFL learners perform differently in writing individually versus writing individually using a bilingual dictionary in terms of spelling, morphology and syntax?

\section{B. Participants}

The participants in the study were 4 male and 22 female pre-intermediate English language learners aged between 18 to 25, with an average age of 22, at one of the English language institutes in Iran. All had taken an OPT placement test based on the results of which only pre-intermediate learners were selected. They had learnt English as a foreign language on average for six years at junior high and high school and they also had studied English in the institute for one year. The participants were all Iranian Persian speakers.

\section{Tasks}

The participants were required to write three narrative writings based on three different picture-cued stories which were chronologically sequenced. The picture-cued stories were taken from the book "Can you believe it?" (Huizenga \& Huizenga 2000). The participants completed three writing tasks: one in pairs, one individually and another one using a bilingual Persian to English dictionary. Before completing the tasks, they were given three reading passages which were the stories of the pictures in order to provide them with the input they needed to decipher the story so that the task would not be demanding on the part of the participants. They were given five minutes to read the texts but were not allowed to take notes. Then the texts were collected and the picture-cued stories were given to the participants.

\section{Procedure}

Thirteen pairs of participants (i.e., 26 of the learners who had self-selected into pairs) completed a narrative writing task. While they were working on the task, their interactions were recorded and subsequently transcribed for analysis. The same participants completed two other narrative tasks, one individually and another individually while using a bilingual Persian to English dictionary.

The writings were completed under time limits thus simulating a testing environment. A pilot test was administered in the three different task conditions before administering the major tasks to determine the time needed to complete each task. However, as a result of previous research which has shown that pairs take longer time to complete tasks than individuals (Storch, 2005), the pairs and individuals were allocated a different amount of time. The pairs were given 20 minutes to complete the narrative task and when writing individually, they were given 15 minutes on the writing using dictionary and 10 minutes on individual writing. The writing tasks were run in three subsequent days in order to avoid learning.

\section{RESULTS}

In order to determine whether there were any identifiable differences in the writings completed by the participants working in pairs, and those completed by the participants working individually, the writings were analyzed for accuracy focusing on, spelling, morphology and grammar. The measurement was calculated in an obligatory context. For spelling, this was done by calculating the number of spelling errors divided by the total number of words in each narrative.

Morphological errors (both derivational and inflectional) were measured in terms of the total number of errors divided by the total number of words. Grammar was measured by the proportion of erroneous clauses of all clauses. All proportions were calculated in percentages.

Figure 1. shows the rate of spelling errors in each of the three conditions. Apparently, there has occurred a decrease in the rate of errors in individual writing using a dictionary and in pair writing (4.5\% in individual writing, $3.7 \%$ in individual writing using a dictionary, and $3.6 \%$ in pair writing). It seems that interaction and dictionary use similarly contribute to accuracy in spelling; though this effect does not seem to be significant as the results of an ANOVA performed on mean percentages of errors indicted no significant difference between performance on the three tasks $(\mathrm{F}=.868 ;=.425)$. 


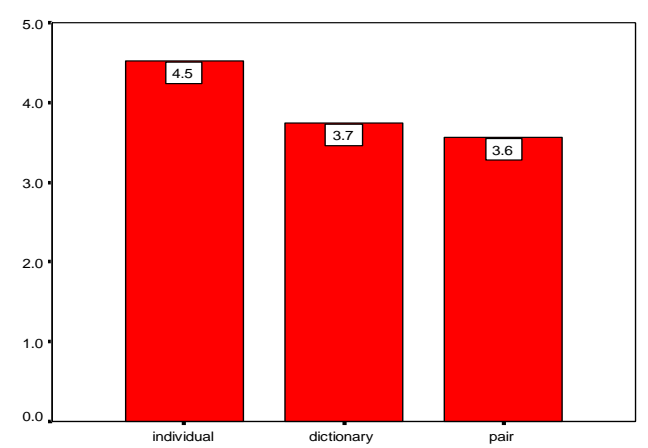

Figure 1. Mean percentages of spelling errors in the three tasks

A similar pattern is observed in the participants performance with regard to morphological errors while the decrease is more obvious in pair writing. The morphological errors were $13 \%$ and $12 \%$ in individual writing and individual writing using a dictionary tasks respectively. This rate has decreased to 5\% in the pair writing task, indicating $95 \%$ accuracy when learners were involved in interaction with their peers. In order to find whether these differences were significant, an ANOVA was performed on the error mean scores, the results of which indicated significant differences between performance on the three tasks $(\mathrm{F}=4.79 ; \mathrm{p}=.012)$. Post hoc results located the difference between individual writing and pair writing $(\mathrm{p}=.017)$ and individual writing using a dictionary and pair writing $(.034)$.

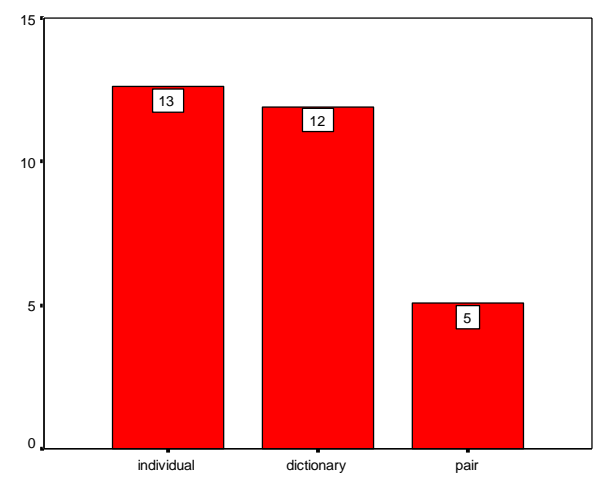

Figure 2. Mean percentages of morphological errors in the three tasks

In other words, only collaboration had positive effect on the correct use of morphology compared to the other two writing tasks.

As for syntactic errors, The mean percentages were $48 \%$ for individual writing, $58 \%$ for individual writing using a dictionary and $29 \%$ in pair writing (Figure 3). Mean differences were found to be significant $(F=10.489, p=.000)$. Pair wise comparison Scheffe tests located the differences between pair writing and both individual writing $(\mathrm{p}=.014)$ and individual writing using a dictionary $(\mathrm{p}=.000)$. In other words, the two individual writing task were not found to be different although mean percentage for individual writing using a dictionary was higher indicating more errors syntactic errors appeared when learners were using a bilingual dictionary.

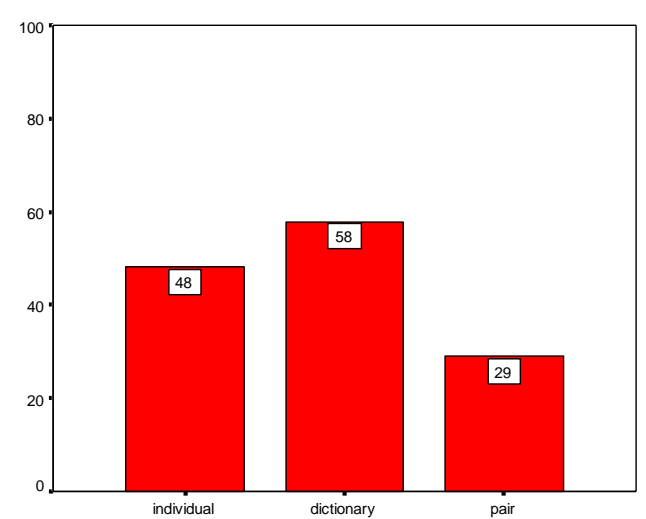

Figure 3. Mean percentages of syntactic errors in the three tasks 
In summary, the results indicated a positive effect for pair writing on the accuracy of L2 learners' in terms of correct use of words and clause structures. The results also showed that using a dictionary did not improve L2 learners' writing even for their morphological errors.

\section{Analysis of the pair interactions}

Five of the thirteen transcripts of the pair interactions were randomly selected for a detailed analysis of the processes the learners were engaged in while they were composing their narratives. The pair dialogues were analyzed at three levels: planning, composing and revising. For this purpose, three distinct phases of the writing process were identified, and the time spent on each phase was noted. These consisted of time spent on planning, which occurred before the learners began to write their texts, time spent composing or actually writing the texts, and revision activities, where the entire text was revised after composing was complete. The aim here was to examine how students approached the writing task rather than calculating the exact time spent on each phase of writing.

The time spent on the different phases (planning, composing, and revising) is shown in Table 1. As would be expected, the learners spent most of the time on the composition phase of the task, with planning taking approximately $15 \%$ of the time, and less than $5 \%$ of their time focused on revisions. The learners went through two types of planning: some planned their writings before the composing phase, but most of the learners went through the planning while composing their narratives.

However, there were differences between pairs. Some learners spent more time on planning their narratives, while other pairs focused on the composing process rather than on planning or revising their writing.

TABLE 1.

PROPORTIONS OF TIME SPENT ON DIFFERENT PHASES OF THE PAIR WRITING TASK

\begin{tabular}{|l|l|l|l|}
\hline Phases & Average (minutes) & Average (\%) & Min-Max \\
\hline Planning & 2.9 & 14.50 & $0-7$ \\
\hline Composing & 16.07 & 80.35 & $11-18$ \\
\hline Revising & 1.03 & 5.15 & $2-5$ \\
\hline
\end{tabular}

In the planning phase, the participants brainstormed on the content of the reading passages they read before starting their writings in order to agree upon organization of the story and to see whether they comprehended the story correctly. As for the composing phase, they spent most of their time on sharing their ideas regarding the content of the narrative. They also corrected themselves on grammatical, morphological and in few cases spelling errors. In revising their writings, the participants re-read the written texts and focused on editing for grammatical accuracy. In some cases, some learners revised their writings during the composing phase as can be seen in the extracts below.

Extract 1. Spelling (correction for spelling)

Hossein: he tought to... to become a mountain climber. How do you spell "tought"?

Abbas: $t-h-o-u-g-h-t$

Hossein: All right. He thought to......

Extract 2. Morphology (selection of $3^{\text {rd }}$ person singular "s")

Yasaman: so he go to US.

Neda: No, he goes to US.

Yasaman: right, he goes to US.

Extract3. Morphology (selection between singular or plural noun)

Parvaneh: he went mountain climbing to....to...

Ali: to achieve his goals

Parvaneh: goals or goal?

Ali: goals

Parvaneh: No, it is one goal.

Ali: Ah... yes, so he went mountain climbing to achieve his goal.

Extract 4. Grammar (selection between object pronouns and possessive adjectives)

Sara: but after that he thought about him important goal.

Nasim: him important goal or his important goal?

Sara: His....his important goal.

Nasim: ok. He thought about his important goal.

Extract 5. Grammar (choice of definite article)

Negar: doctors designed artificial foot for him.

Mahshid: an artificial foot.

Negar: an artificial foot?

Mahshid: Yes, an artificial foot.

Negar: hum, you're right.

Extract 6. Spelling ( not knowing the correct spelling)

Nasim: He thought about marriage

Sara: How do you spell marriage?

Nasim: I think it is m-a-r-r-i-g-e. Yes? 
Sara: Yes, It's true.

\section{DISCUSSION}

Researchers working within the framework of the Interaction Hypothesis of L2 acquisition claim that the range of interactional processes during interactive tasks such as negotiation of meaning, provision of feedback, and production of modified output would promote L2 production (e.g., Gass and Mackey, 2007; Mackey, 2007a, 2007b; McDonough, 2004). As it was explained previously, the focus of this study was to investigate the effect of collaborative writing on accuracy compared to individual and individual using bilingual dictionary writing.

Our study is the first step in investigating the impact of collaboration in a foreign language context in which it measures the new aspects of accuracy (i.e. spelling, morphology, and structure). In previous studies (Donato.1998; Storch, 2002, 2003; Wigglesworth, G., \& Storch, N., 2009), pair and individual writings were compared and the results revealed that collaboration had positive impact on the written production which supports the Interaction Hypothesis claim that the opportunity for collaborative work enhances negotiation of meaning. These negotiations make the input more comprehensible which in turn facilitates L2 acquisition (Long, 1983, 1996).

Thus, in order to see whether the use of dictionary can produce the same results, we added an innovative aspect to our study in which the participants were required to use a bilingual dictionary to write their narratives. In the comparison between individual and individual using bilingual dictionary writings, using bilingual dictionary did not have any significant effect on the correct use of morphology. So, it can be concluded that using dictionary cannot contribute to the better use of morphology. It is probably because the participants just looked up the words in the dictionary and did not concentrate on derivational and inflectional morphemes. Surprisingly, the use of bilingual dictionary had negative effect on grammar. The reason could be, as for morphology, the learners' focus on finding words in dictionary distracted their attention from grammar which consequently resulted in negative impact of dictionary on grammar.

The results revealed that collaboration did not have any effect on the spelling in comparison with individual writing and individual using dictionary writing. This might be because spelling as an important element in writing does not receive much attention in English language institutes in Iran. It is also possible that because the participants had previously learnt the spelling of the vocabularies they looked up in the dictionary, they did not check the spelling of the words in the dictionary. However, collaboration had positive effect on morphology and grammar compared to both individual and individual using bilingual dictionary writings. While Interaction Hypothesis claims that the opportunity for interaction mostly improves negotiation of meaning in terms of vocabulary, this study revealed that collaboration also enhances the grammatical accuracy of the written production. Furthermore, the findings of this study are in line with findings of the study done by Wigglesworth, G., and Storch, N. (2009) in which they concluded that collaborative writing had significant effect on the accuracy of essay writing.

Analysis of the paired dialogues suggests that the learners went through three phases while composing their narratives: planning, composing, and revising. The learners who planned before composing, brainstormed on the content of the reading passages they read before starting their writings in order to agree upon the organization of the story and to see whether they understood the story correctly. The majority of the learners planned their writings while composing their narratives. They shared their ideas discussing the content and grammar of their writings. They provided feedback to each other on correcting the grammatical and in few cases the spelling errors. According to Baleghizadeh (2010) "Working in pairs provides learners with opportunities to give and receive feedback, and respond to it by modifying their output. Metaphorically, pair work activities create fertile farmland in which the seeds of negative feedback and modified output easily grow" (p. 723). Moreover, the writings provided by learners using online planning (planning while composing) were more accurate which is compatible with what Ellis and Yuan (2004) found in their study which investigated the effects of planning on fluency, accuracy, and complexity in second language narrative writing: “.. the opportunity for on-line planning resulted in more accurate written production "(p.17). As for the revising phase of the writing process, the learners spent less time since most of them corrected the errors and provided feedback to each other while composing. They re-read the text and corrected the grammatical and spelling errors.

In general, working in pairs learners receive feedback from each other on different aspects of the language which can help them learn from each other. Another point to mention is that weaker learners can benefit from collaboration through learning from their partners. The teachers can gain insight from collaborative work in the classroom to further the opportunities for the learners to use more pair work activities. Also syllabus designers can incorporate collaborative activities in designing the courses. Material developers may take into account the use of more pair work activities in the materials they develop for the classroom use.

In this study, we investigated the effect of pair work on picture-cued narrative writing on the accuracy of intermediate foreign language learners focusing on spelling, morphology, and grammar. Further studies can be done to investigate the effect of collaborative writing on other types of writing or on other aspects like complexity and fluency. Also worthy of investigation is the study of the effect of collaboration on different proficiency levels to see whether learners of different proficiency perform differently on the tasks. Another line of the study which can add valuable knowledge to the literature is the investigation to see whether collaborative writing is internalized by the learners during the learning process. Furthermore, in this study we used bilingual dictionary, other studies can use monolingual 
dictionary to see if it has any or different effect. Another fruitful study to do is, to assign a task to the learners in which they concentrate on parts of speech in their writings.

\section{REFERENCES}

[1] Adams, D., \& Hamm, M. (1996). Cooperative learning. Critical thinking and collaboration across the curriculum (2nd ed.). Springfield, IL: Charles Thomas.

[2] Baleghizadeh, S. (2010). The Impact of Peer Interaction on an Editing Activity in EFL Classes Language Teaching and Research, Vol. 1, No. 5, pp. 721-727.

[3] Bargh, J. A., \& Schul, Y. (1980). On the cognitive benefits of teaching. Journal of Educational Psychology, 72(5), 593-604.

[4] Barnes, D., \& Todd, F. (1977). Communication and learning in small groups. London: Routledge

[5] Bossert, S. T. (1988-1989). Cooperative activities in the classroom. Review of Research in Education, 15, $225-252$.

[6] Bygate, M. (1988). Units of oral expression and language learning in small group interaction. Applied Linguistics, 9(1), 59-82.

[7] Daiute, C. (1986). Do 1 and 1 make 2? Patterns of influence by collaborative authors. Written Communication, 3(3), 382-408.

[8] DiCamilla, F. J., \& Anton, M. (1997). Repetition in the collaborative discourse of L2 learners: A Vygotskian perspective. The Canadian Modern Language Review, 53, 609-633.

[9] Donato, R. (1988). Beyond group: A psycholinguistic rationale for collective activity in second-language learning. Newark: University of Delaware.

[10] Donato, R. (1994). Collective scaffolding in second language learning. In J. P. Lantolf, \& G. Appel (Eds.), Vygotskian approaches to second language research (pp. 33-56). Norwood, NJ: Ablex.

[11] Fuchs, L. S., Fuchs, D., Hamlett, C. L., Phillips, N. B., Karns, K., \& Dutka, S. (1997). Enhancing students' helping behavior during peer-mediated instruction with conceptual mathematical explanations. The Elementary School Journal, 97(3), $223-249$.

[12] Ferris, D. (2003). Response to student writing: Implications for second language students. Mahwah, NJ: Lawrence Erlbaum Associates.

[13] Fung, Y. M. (2010). Collaborative writing features. RELC Journal, 41(1), 18-30.

[14] Higgins, L., Flower, L., \& Petraglia, J. (1992). Planning text together. The role of critical reflection in student collaboration. Written Communication, 9(1), 48-84.

[15] Johnson, D.W., \& Johnson, R. T. (1974). Instructional goal structure: Cooperative, competitive, or individualistic. Review of Educational Research, 44(2), 213-240.

[16] Johnson, D. W., \& Johnson, R. T. (1979). Conflict in the classroom: Controversy and learning. Review of Educational Research, 49(1), 51-70.

[17] Johnson, D. W., \& Johnson, R. T. (1989). Cooperation and competition: Theory and research. Edina, MN: Interaction Book Company.

[18] Johnson, D. W., \& Johnson, R. T. (1992). Positive interdependence: Key to effective cooperation. In R. Hertz- Lazarowitz \& N. Miller (Eds.), Interaction in cooperative groups: The theoretical anatomy of group learning (pp. 174-199). New York: Cambridge University Press.

[19] Gass, S.M., Mackey, A., (2007). Input, interaction and output in SLA. In: Williams, J., Van Pattern, B. (Eds.), Theories in Second Language Acquisition. Lawrence Erlbaum, Mahwah, NJ, pp. 175-199.

[20] Keys, C.W. (1994). The development of scientific reasoning skills in conjunction with collaborative assessments. An interpretive study of 6-9th grade students. Journal of Research in Science Teaching, 3(9), 1003-1022.

[21] Kumpulainen, K., \& Mutanen, M. (1999). The situated dynamics of peer group interaction: An introduction to an analytic framework. Learning and Instruction, 9, 448-474.

[22] Kumpulainen, K., \& Mutanen, M. (2000). Mapping the dynamics of peer group interaction: A method of analysis of socially shared learning processes. In H. Cowie \& G. v. d. Aalsvoort (Eds.), Social interaction in learning and instruction: The meaning of discourse for the construction of knowledge (pp. 144-160). New York: Elsevier Science.

[23] Lazarowitz, R., \& Karsenty, G. (1990). Cooperative learning and students' academic achievement, process skills, learning environment, and self-esteem in tenth-grade biology classrooms. In S. Sharan (Ed.), Cooperative learning: Theory and research (pp. 123-149). New York: Praeger.

[24] Leki, I. (1993). Reciprocal themes in reading and writing. In J. Carson, \& I. Leki (Eds.), Reading in the composition classroom: second language perspectives (pp. 9-33). Boston: Heinle \&Heinle.

[25] Leki, I. (2001). 'A narrow thinking system': Nonnative-English-speaking students in group projects across the curriculum. TESOL Quarterly, 35(1), 39-67.

[26] Leung, C. (2005). Classroom teacher assessment of second language development: Construct as practice. In E. Hinkel (Ed.), Handbook of research in second language teaching and learning. Mahwah, NJ: Lawrence Erlbaum.

[27] Long, M. (1983). Native speaker/non-native speaker conversation in the second language classroom. In M. Clarke \& J. Handscombe (Eds.), On TESOL'82: Pacific perspectives on language and teaching. Washington, D. C.: TESOL.

[28] Long, M. (1996). The role of the linguistic environment in second language acquisition. In W. Ritchie \& T. Bhatia (Eds.), Handbook of second language acquisition. New York: Academic Press.

[29] Mackey, A., (2007a). Introduction: the role of conversational interaction in second language acquisition. In: Mackey, A. (Ed.), Conversational Interaction in Second Language Acquisition. Oxford University Press, Oxford, pp. 1-26.

[30] Mackey, A., (2007b). Interaction as practice. In: DeKeyser, R. (Ed.), Practice in Second Language. Cambridge University Press, Cambridge, pp. 85-110.

[31] McDonough, K., (2004). Learner-learner interaction during pair and small group activities in Thai EFL context. System 32, 207-224.

[32] Mutch, A. (1998). Employability or learning? Group work in higher education. Education and Training, 40(2), 50-56.

[33] Nystrand, M., \& Brandt, D. (1989). Response to writing as a context for learning to write. In C. M. Anson (Ed.), Writing and response: Theory, practice, and research (pp. 209-230). Urbana, IL: National Council of Teachers of English. 
[34] Palincsar, A. S., Brown, A. L.,\&Campione, J. C. (1993). First-grade dialogues for knowledge acquisition and use. In E. A. Forman, N. Minick, \& C. A. Stone (Eds.), Contexts for learning: Sociocultural dynamics in children's development (pp. 43-57). New York: Oxford.

[35] Slavin, R. E. (1990). Research on cooperative learning: Consensus and controversy. Educational Leadership, 47(4), 52-54.

[36] Slavin, R. E. (1990). Cooperative learning: Theory, research, and practice. Boston: Allyn \& Bacon.

[37] Slavin, R. E. (1992). When and why does cooperative learning increase achievement? Theoretical and empirical perspectives. In R. Hertz-Lazarowitz \& N. Miller (Eds.), Interaction in cooperative groups: The theoretical anatomy of group learning (pp. 145-173). New York: Cambridge University Press.

[38] Storch, N. (2002). Patterns of interaction in ESL pair work. Language Learning, 52(1), 119-158.

[39] Storch, N. (2003). Relationships formed in dyadic interaction and opportunity for learning. International Journal of Educational Research, 37(3/4), 305-322.

[40] Storch, N. (2005). Collaborative writing: Product, process, and students' reflections. Journal of Second Language Writing, 14(3), 153-173.

[41] Strauss, P., \& U, A. (2007). Group assessments: Dilemmas facing lecturers in multicultural tertiary classrooms. Higher Education Research \& Development, 26(2), 147-161.

[42] Swain, M., \& Lapkin, S. (1998). Interaction and second language learning: two adolescent French immersion students working together. Modern Language Journal, 82(3), 320-337.

[43] Swing, S. R., \& Peterson, P. L. (1982). The relationship of student ability and small-group interaction to student achievement. American Educational Research Journal, 19(2), 259-274.

[44] Vygotsky, L. S. (1978). Mind in society. The development of higher psychological processes. Cambridge, Mass: Harvard University Press.

[45] Webb, N. (1989). Peer interaction and learning in small groups. International Journal of Educational Research, 13, 21-39.

[46] Webb, N.M. (1991).Task-related verbal interaction and mathematics learning in small groups. Journal for Research in Mathematics Education, 22(5), 366-389.

[47] Webb, N. M., \& Palincsar, A. S. (1996). Group processes in the classroom. In D. C. Berliner \& R. C. Calfee (Eds.), Handbook of educational psychology (pp. 841-873). New York: Simon \& Schuster Macmillan.

[48] Wells, G., Chang, G. M., \& Maher, A. (1990). Creating classroom communities of literate thinkers. In S. Sharan (Ed.), Cooperative learning: Theory and research (pp. 95-122). New York: Praeger.

[49] Wigglesworth, G., \& Storch, N. (2009). Pair versus individual writing: Effects on fluency, complexity and accuracy. Language Testing, 26: 445.

Manijeh Youhanaee holds a PhD in language and linguistics from the University of Essex. She has co-authored with Badrizadeh “A Descriptive Dictionary of Theories of Generative Grammar". She has published a number of articles on the teaching/ acquisition of different English syntactic properties by native speakers of Persian. She teaches MA and PhD courses in linguistics, generative grammar, TEFL and SLA. Her areas of interest include syntactic theory, acquisition of L2 \& L3 syntax and issues in teaching and learning English as a second/foreign language.

Afsaneh Rahimi Tehrani (1985, Isfahan, Iran) is an MA graduate from university of Isfahan. Her areas of interest are language learning and teaching, and young EFL learners. She has five years experience of teaching English to EFL young learners, teenage learners, and adults.

Faramarz Piri received his M.A. in TEFL from University of Isfahan, Iran. His areas of interest are Second language Acquisition and language teaching methodology. 